2. Virtuoso // The New Grove Dictionary of Music and Musicians / ed. by S. Sadie. - London : Grove, 2001. - Vol. 26. - P. 789.

3. Кунау, И. Музыкальный шарлатан // Музыкальная эстетика западной Европы XVII-XVIII веков / сост. текстов и общ. вступ. ст. В. П. Шестакова. - Москва : Музыка , 1971. - С. 225-233.

4. Бородин, Б. «Пианист пианистов» и его «этюды этюдов» // Фортепиано. - 2009. - № 1/2. C. $40-50$.

5. Окраинец, И. Доменико Скарлатти. Через инструментализм к стилю. - Москва : Музыка, 1994. $-208 \mathrm{c}$.

6. Максимов, Е. Фортепианное творчество Л. Бетховена в контексте музыкальной критики и исполнительских тенденций конца XVIII - первой трети XIX века : дис. ... канд. искусствоведения: 17.00.02 ; Московская гос. консерватория им. П. И. Чайковского. - Москва, 2003. -315 с.

7. Рубинштейн, А. Лекции по истории фортепианной литературы // Литературное наследие : в 3 т. / сост., текстолог. подготовка, коммент. и вступ. ст. Л. А. Баренбойма. - Москва : Москва, 1986. - Т. 3 : Письма, 1872-1894. Лекции по истории фортепианной литературы. - С. 146-201.

8. Терентьева, Н. А. История и теория музыкальной педагогики и образования : учеб. пособие : в 2 ч. - Санкт-Петербург : Образование, 1994. - Ч. 2. - 148 с.

9. Яконюк, В. Л. Исполнительская школа как фактор музыкального искусства: вопросы методологии // Весці Беларускай дзяржаўнай акадэміі музыкі. - 2007. - № 10. - С. 48-58.

10.Николаев, Л. В. Статьи и воспоминания современников. Письма. - Ленинград : Сов. композитор. ; Ленингр. отд-ние, 1979. - 328 с.

Irina Yu. Onoshko, Ph. D. in Art History, Associated Professor Belarusian State Academy of Music (Minsk, Belarus) onoshkoira@yandex.ru

\title{
PIANO VIRTUOSITY PHENOMENON IN HISTORICAL RETROSPECTIVE
}

Abstract. The paper outlines the author's view on historical and cultural context of development of an idea about perfect - artistically and technically - level of performing musical pieces written for a pianoforte in various periods of history (Barocco, Classicism, Romanticism, the $20^{\text {th }}$ century - the beginning of the $21^{\text {st }}$ century). The author stresses out a strong relation between criteria of assessment of aesthetic value of virtuosity, and genre peculiarities of a composer's creativity and technical originality of performing, as well as dominant views on art of improvisation. The paper uncovers development of various times musicians' views on phenomenon of virtuosic performing of piano music.

Keywords: virtuosity, a virtuoso, pianoforte art, art of composing, musical performing activity, art of musical performing, a composer-virtuoso, romantic virtuosity.

УДК 379.8:792(571.1)“1960-e/1980-e”

DOI: $10.32340 / 2414-9101-2019-1-58-63$

Я. А. Олейник, кандидат исторических наук Алтайский государственный институт культуры (Барнаул, Россия) yana-ol@mail.ru

\section{РАЗВИТИЕ ЛЮБИТЕЛЬСКОГО ТЕАТРАЛЬНОГО ИСКУССТВА ЗАПАДНОЙ СИБИРИ В 1960-1980-Х ГОДАХ}

Аннотация. Охарактеризованы особенности творческой эволюции любительского театрального движения Западной Сибири 1960-1980-х гг. под влиянием контактов с крупными профессиональными театрами региона. Автор аргументирует тезис о влиянии разработанной в 1960-1970-х гг. модели «шефской» помощи государственных театров самодеятельным коллективам региона на 
облик культурной жизни региона. По итогам анализа архивных документов и материалов установлен перечень основных форм творческого сотрудничества, характерных для указанного периода отечественной истории: реализация совместных творческих проектов, консультирование ведущих специалистов профессиональных театральных коллективов актёров любительских театров по творческим вопросам, передача материальных ценностей в распоряжение любительских театральных коллективов. На взгляд автора, система оказания «шефской» помощи профессиональными театральными коллективами любительским театрам, позволившая в своё время количественно и качественно увеличить показатели работы творческих коллективов, и сохраняет свою ценность и полезность в современных социально-культурных условиях.

Ключевые слова: театр, профессиональное театральное искусство, любительская театральная деятельность, любительское театральное движение Западной Сибири, «шефство», социально-культурное пространство, народные театры, театральные фестивали, культурное обслуживание населения отдалённых районов.

Любительский театр как социально-культурный институт имеет большую значимость. Данный вид художественного творчества населения направлен на сохранение традиционных нравственно-эстетических устоев, ценностей, присущих культуре, воспитание бескорыстного служения любимому делу, формирование чувства коллективизма. Потому любительский театр, как форма культурно-творческой деятельности требуют изучения накопленного опыта в целях формирования модели, способствующей возрождению интереса населения к театральному искусству, особого внимания со стороны всех, заинтересованных в развитии духовной жизни общества.

Период 1960-х - 1980-х годов отмечен ростом массовости, вовлечением в художественное творчество большого числа населения [1, с. 61]. Любительские театры функционировали в большинстве населенных пунктов, во всех крупных организациях и на предприятиях региона, в школах, оказывая позитивное влияние на функционирование социально-культурной сферы и обогащение духовной жизни региона. Огромное влияние на популяризацию любительского творчества оказывали профессиональные театральные коллективы, посредством повышения его количественных и качественных показателей.

Для оказания творческой помощи в театрах повсеместно создавались консультационные пункты, практиковались творческие семинары и лаборатории. В 1965 году на базе Новокузнецкого и Прокопьевского театров проведены трехдневные семинары руководителей сельской самодеятельности и организаторов университетов культуры . Новосибирский театр оперы и балета (1965) открыл университет культуры в Тогучинском районе, а в Тутовском совхозе и колхозе «Знамя коммунизма» оказал помощь в организации хорового коллектива [2]. Художник Новосибирского театра оперы и балета С. И. Селиверстов (1967) подготовил эскизы для оформления ДК Тогучинского района [3]. Часть коллектива Новосибирского театра оперы и балета (1967) выезжали для оказания методической помощи, входили в состав районных жюри по смотру художественной самодеятельности [4]. В 1972 году был создан консультационный совет для самодеятельных коллективов края под руководством главного режиссера Алтайского театра юного зрителя 3. И. Китая, получившего за творческие и организационные достижения признание не только в регионе, но и за его пределами. При доме актера в Новосибирске был открыт театр чтеца под руководством 3. Бахтиной [5]. При Омском драматическом театре в 1974 году создан клуб молодых рабочих. Для первого просмотра и обсуждения был выбран спектакль «Человек со стороны» И. Дворецкого.

В целях систематизации оказания шефской помощи самодеятельным коллективам местными управлениями культуры разрабатывались наиболее приемлемые для конкретной территории модели. Широкое распространение получила практика закрепления отдельных творческих коллективов, отдаленных районов за профессиональным театром. Омский драмтеатр постоянно оказывал помощь народным театрам в Называевке и Таре, народному театру Дома офицеров. При театре так же постоянно работал консультационный пункт для театральной самодеятельности [6]. Кемеровский облдрамтеатр взял шефство над Тяжинским народным театром, Прокопьевский городской театр над народным театром станции Трудармейская, Новокузнецкий театр сотрудничал с народным театром Запсиба, кукольные театры области оказывали помощь детским кукольным 
коллективам городов и сел. Между некоторыми театральными и самодеятельными коллективами устанавливались прочные творческие связи. Алтайский краевой театр музыкальной комедии много лет сотрудничал с Кытмановским народным театром оперетты. Алтайский краевой театр кукол принимал активное участие в создании самодеятельного кукольного театра Горно-Алтайской селекционной станции, руководителям которого была продемонстрирована технология кукольного театра непосредственно на репетициях и в цехах. В 1967 году Омскому театру музыкальной комедии было поручено шефство над Калпачинским народным музыкальным театром [7]. В 1971 году артисты театра оперетты Кузбасса взяли шефство над политическим клубом «Радуга» в селе Новостройка [8]. В целом шефская помощь самодеятельным и народным коллективам устраивала заинтересованные стороны. Однако имели место и недовольства дирекции профессиональных театров, прикрепленным любительским коллективом. В 1968 году Новосибирский театр оперы и балета выступил с предложением к управлению культуры области о смене подшефного района, поскольку материально-техническая база учреждений культуры Тогучинского района была слаба и не позволяла оказывать шефскую помощь на достаточном уровне, добиваться успехов в творческих смотрах [9].

Развитие самодеятельных творческих коллективов предопределило укрепление и совершенствование творческих связей профессиональных театров с сельскими районами. В подшефных районах театров неизменно повышалась театральная культура населения. Занятия, проводимые театрами регулярно, а не от случая к случаю, эстетически воспитывали население, улучшали качество восприятия спектакля.

Партийно-государственные органы, обеспечивающие деятельность профессиональных коллективов, стремились создавать долгосрочные творческие проекты. Кемеровское управление культуры придавало большое значение развитию самодеятельного искусства в регионе. В рассматриваемый период работа театральных коллективов Кузбасса с подшефными театрами и районами была стабильна. Благодаря чему самодеятельное искусство Кузбасса совершило качественный «скачок» от количественного многообразия к качественно-художественному содержанию работы коллективов $[10$, с. 69$]$.

Большинство районов Алтайского края имели свои любительские творческие коллективы. Во многих районах действовали народные театры. Надзор за оказанием шефской помощи осуществлялся местными органами власти, которые уделяли этому вопросу значительно больше внимания, чем собственно творческой деятельности театров. Организация шефской помощи возлагалась на Алтайское отделение Всероссийского театрального общества. Им определялись и закреплялись за отдельными творческими коллективами районы обслуживания, разрабатывалась методика оказания шефской помощи. В 1965 году Алтайским краевым театром драмы был разработан план мероприятий по оказанию помощи, прикрепленным к нему народным театрам с. УстьПристань и с. Смоленское. План предусматривал выявление потребностей народных театров, рассмотрение репертуара, проведение семинаров для режиссеров и художников народных театров совместно с Домом народного творчества. Планировалась организация выездной группы творческих работников театра для оказания практической помощи. Приглашались артисты, занятые в спектакле «Чти отца своего» на одноименный спектакль краевого театра [11]. Однако систематичность в работе алтайских театров не была установлена. В 1967 году местными партийными органами была отмечена эпизодичность шефской помощи. Актеры редко посещали, закрепленные за ними самодеятельные коллективы, не были организованны кружки для руководителей художественной самодеятельности.

К середине 70-х годов XX века качество шефской работы существенно улучшилось. Алтайскому отделению ВТО удалось добиться систематичности в работе профессиональных театральных коллективов. Профессиональные актеры не только выезжали для оказания практической помощи народным театрам, но и принимали участие в отдельных постановках. В спектакле народного театра Ребрихинского района «Трибунал» по пьесе А. Макаенка выступили артисты Л. Двоеглазов, А. Шелякина, Ю. Кузьмина. Актер краевого театра Л. Двоеглазов выезжал в этот театр для проведения репетиций. Помощь самодеятельным театральным коллективам осуществлялась также в возможности присутствия на премьерных спектаклях профессиональных театров режиссерам и ведущим актерам, в посещении отдельных репетиций. 
В конце 1970-х годов в отдельных районах заметно снизился уровень работы с самодеятельностью. Томское отделение ВТО отмечало, что ослабло понимание состояния самодеятельного драматического искусства, профессиональные театры перестали влиять на репертуар народных театров. Дирекции театров в качестве основной причины снижения интереса к деятельности указывали отсутствие информации о количестве и объеме помощи необходимой самодеятельным коллективам. С целью прояснения ситуации была организована зональная лаборатория режиссеров народных театров и создан консультационный пункт для руководителей художественной самодеятельности [12, с. 350].

Западносибирские профессиональные театральные коллективы оказывали большое влияние на деятельность народных театров, учили бороться с тенденцией подражательства, воспитывали вкус к самостоятельным оригинальным решениям, подбору репертуара и повышению постановочной культуры [13]. Ярким примером творческого сотрудничества стал опыт Кемеровского драматического театра с народным театром поселка Тяжинский. Театры синхронно поставили спектакль по пьесе Г. Боровика «Интервью в Буэнос-Айресе» (1976) для возможности замены самодеятельных актеров профессиональными, что давало самодеятельным актерам профессиональный опыт работы над ролью. В спектаклях народного театра были задействованы ведущие актеры областного театра - заслуженный артист РСФСР Борис Суров, народная артистка РСФСР Валентина Литвинова и Станислав Балакин, артист В. Руденко [14].

Самодеятельным коллективам постоянно оказывалась и материальная помощь, путем передачи некоторого театрального имущества. Материальный аспект помощи проявлялся в предоставлении костюмов, реквизита, световой аппаратуры, материалов для оборудования сцен и т. д. В 1968 году в качестве шефской помощи сельской самодеятельности были переданы костюмы и ноты к спектаклю «100 чертей и одна девушка» Маслянинскому отделу культуры, Мошковскому отделу культуры - пианино и рояль, Северному ДК - костюмы и ноты к спектаклю «Умные вещи»[15]. Материальная помощь была оказана кукольным театрам при Домах культуры Сорокинского и Троицкого районов Алтайского края. Кемеровский областной драмтеатр передал Мариинскому народному театру приборы, предметы бутафории, оказал помощь театральному коллективу школы №62 костюмами [16]. Театром оперетты Кузбасса оказывалась помощь в техническом оснащении районного дома культуры, которому были переданы электрооборудование, одежда сцены [17].

Наиболее высокую организационно-творческую форму любительского искусства представляли народные самодеятельные коллективы, по исполнительскому мастерству нередко не уступающие профессиональным. К последним можно отнести коллектив Томского народного театра оперетты, действовавшего в городе Томск-7, народный театр Омской области, Исилькульский народный театр, которые неоднократно становились лауреатами всероссийских конкурсов самодеятельного творчества. Под руководством профессиональных творческих работников народные и любительские коллективы Западной Сибири добивались признания на различных смотрах и конкурсах. В июле 1973 года на зональном смотре Сибири народный театр Каменского района Алтайского края со спектаклем «В ночь лунного затмения» М. Карима стал лауреатом. Немалая заслуга в этом принадлежит главному режиссеру краевого театра С. К. Шпанову, который провел ряд репетиций перед смотром [18]. Под руководством режиссера Алтайского краевого театра юного зрителя В. А. Зайцевой народный театр Троицкого района поставил спектакль «Июнь, начало лета», получивший на зональном смотре диплом III степени. Подшефный Омскому драматическому театру Называевский народный театр в течение нескольких лет (1966-1970) завоевывал диплом I степени на региональных смотрах и конкурсах. Показывал свои работы в Москве на Кремлевской сцене.

Качественная помощь любительскому художественному творчеству не оставалась без внимания партийно-государственных органов. В декабре 1970 года «Красный факел» в честь 50летия и за заслуги в области развития советского театрального искусств был награжден Орденом Трудового Красного знамени [19]. В 1972 году за шефскую работу на селе коллектив Омского драмтеатра получил переходящее знамя и денежную премию Министерства культуры РСФСР и ЦК Профсоюза культуры [20]. За работу с самодеятельными коллективами Алтайский краевой театр юного зрителя в 1973 году был награжден Министерством культуры СССР и ЦК профсою- 
зов работников культуры, рабочих и служащих сельского хозяйства денежной премией и вымпелом за культурно-шефскую работу на селе.

Массовость самодеятельного театрального движения позволила организовать в западносибирском регионе праздник - «Театральная весна», неизменными участниками художественного совета которого становились работники театров. Художественно-артистический и художественно-руководящий состав профессиональных театров был задействован как в подготовке самодеятельных коллективов к смотрам и конкурсам, так и в оценке результатов работы. Особой популярностью «Театральная весна» пользовалась в Кузбассе. Смотры самодеятельных коллективов широко освещались в местной прессе.

Некоторые профессиональные коллективы выступали с творческой инициативой в проведении смотров и конкурсов самодеятельных театральных коллективов. В 1977 году при поддержке управления культуры Новокузнецким театром кукол был проведен 1-й городской смотрфестиваль самодеятельных коллективов театров кукол [21].

Фестиваль в Томской области стал традиционным мероприятием по культурному обслуживанию населения в отдаленных районах. С 1965 года в период навигации на специально оборудованных теплоходах областного управления культуры выезжали десятки профессиональных и самодеятельных коллективов. Мероприятие получило название - Фестиваль «Северное сияние». С помощью плавучих культбаз удавалось провести 800-850 концертов ежегодно в населенных пунктах, расположенных по течению Оби и ее притоков. Мероприятие ежегодно посещали более 100 тысяч жителей. Летом 1878 года в фестивале культуры и искусства «Северное сияние» приняли участие не только театральные деятели Томской области, но и московские артисты [22]. В 1979 году Томским районом Томской области проводилась декада театрального искусства, включавшая в себя просмотр новых спектаклей драматического театра и их обсуждение [23].

С 24 по 30 мая 1979 года в Кемеровской области проводился праздник советской музыки. Он был посвящен пятидесятилетию первого пятилетнего плана и приобрел масштаб большого общественно-политического события. В рамках мероприятия выступили более 500 мастеров музыкального искусства, художественных коллективов, Московский камерный музыкальный театр, Московский государственный хор, симфонический оркестр Новосибирской филармонии и другие [24].

Разработанная в 1960-1970-х годах, модель оказания шефской помощи самодеятельным коллективам региона в значительной степени повлияла на процесс формирования социальнокультурного пространства региона. Внимание, которое уделялось в 1960-1980-х годах вопросам развития художественного творчества населения органами государственной власти и общественными институтами, не идет ни в какое сравнение с настоящим положением дел в этой сфере, и нашло отражение в разнообразных формах деятельности, в том числе шефства, проявлявшегося в систематической работе: консультациях, оказании материальной помощи, реализации совместных творческих проектов, конкурсов, фестивалей. Несмотря на то, что театры развивали общественные связи под давлением местных партийных органов, этот процесс оказывал положительное влияние на развитие любительского художественного творчества населения Западной Сибири, так и на творческую деятельность театров.

\section{Список литературь}

1. Эстетическое воспитание трудящихся Советской Сибири: исторический опыт и современность : сб. науч. тр. - Новосибирск : Ротапринт РПО СО ВАСХНИЛ, 1989. - 165 с.

2. ГАНО. Ф. П. 8405. Оп. 1. Д. 28. Л. 107.

3. ГАНО. Ф. П. 8405. Оп. 1. Д. 31. Л. 22.

4. ГАНО. Ф. П. 8405. Оп. 1. Д. 30. Л. 81.

5. Советская Сибирь. - 1968. - 24 мая.

6. ЦДНИ ОО. Ф. Р. 2738. Оп. 1. Д. 34. Л. 56.

7. ЦДНИ ОО. Ф. П. 3416. Оп. 1 Д. 41. Л. 53.

8. ГАКО. Ф. Р. 984. Оп. 1. Д. 235. Л. 14.

9. ГАНО. Ф. П. 8405. Оп. 1. Д. 32. Л. 41.

10. Штальбаум, Ю. К. Театральное искусство Кузбасса : учеб. пособие. - Кемерово : Из-во Кемеровской гос. акад. культуры и искусств, 2000. - 154 с. : ил. 
11. Красное Знамя. - 1978. - 24 апреля.

12. Родной край: Очерки природы, истории, хозяйства и культуры Томской области.Томск : Изд-во Томского ун-та, 1974. $-401 \mathrm{c.}$

13. ГАКО. Ф. Р. 984. Оп. 3. Д. 5. Л. 16.

14. ГАНО. Ф. Р. 1375. Оп. 1. Д. 559. Л. 79.

15. ГАНО. Ф. Р. 984. Оп. 3. Д. 7. Л. 30.

16. ГАКО. Ф. Р. 1131. Оп. 1. Д. 167. Л. 9.

17. ЦЦНИ ОО. Ф. Р. 2738. Оп. 1. Д. 34. Л. 175.

18. ГАНО. Ф. П. 583. Оп. 1. Д. 45. Л. 53.

19. ЦЦНИ ОО. Ф. Р. 2738. Оп. 1. Д. 36. Л. 138.

20. ГАКО. Ф. Р. 984. Оп. 3. Д. 5. Л.18.

21. ЦДНИ ТО. Ф. 607. Оп. 7. Д. 75. Л. 128.

22. Красное Знамя. - 1979. - 15 марта.

23. РГАНИ. Ф. 5. Оп. 76. Д. 289. Л. 18.

24. ЦДНИ ТО. Ф. 607.Оп. 1. Д. 3909. Л. 1-106.

Iana A. Oleinik, Ph. D. in History Altai State Institute of Culture (Barnaul, Russia) yana-ol@mail.ru

\section{AMATEUR THEATRE ART IN WEST SIBERIA IN THE 1960S - 1980S}

Abstract. The paper describes some peculiarities of creative evolution of amateur theatre movement of West Siberia of the 1960s - 1980s under the influence of relations with major professional theatres located in the region. The author argues a statement about an effect that "patronage assistance" from state theatres to amateur theatre troops model worked out in the 1960s - 1970s had had on a face of cultural life of the region. Analysis of the archival document and materials lets the author to set a list of the key forms of creative collaboration that can be considered as usual for this period of Russian history: common projects, creative consulting of amateur actors, transfer of values and inventory items. On the author's view, system of "patronage assistance" from professional theatres to amateur theatre troops let to improvement quality of work of amateur treaters in that time, and it had kept its usefulness for modern social and cultural situation till now.

Keywords: theatre, professional theatre art, amateur theatrical activities, amateur theatre movement in West Siberia, "patronage assistance", social and cultural space, people's theatre, theatre festivals, cultural service for population of outlying territories. 